\title{
Comparative Study of Garlic Extract Effect on the Expression of Genes Involved in Quorum Sensing in Pseudomonas aeruginosa and the Antibiotic Tobramycin
}

\section{Mansoureh Ghods Zadeh ${ }^{1}$, Soheila Moradi Bidhendi ${ }^{2 *}$, Fatemeh Ashrafi ${ }^{3}$}

1. Master of Microbiology, Department of Microbiology, North Tehran Branch, Islamic Azad University, Tehran, Iran

2. Associate Professor, Razi Vaccine and Serum Research Institute, Agricultural Research, Education and Extension Organization, Tehran, Iran

3. Assistant Professor, Department of Microbiology, North Tehran Branch, Islamic Azad University, Tehran, Iran

10.30699/ijmm.15.1.107

\section{ABSTRACT}

Background: The expression of most genes involved in pathogenesis in Pseudomonas aeruginosa is controlled and regulated by a gene system called quorum sensing (QS). The purpose of this study was to investigate the quorum quenching of garlic extract in preventing the expression of genes involved in QS system of $P$. aeruginosa.

Methods: In the present cross-sectional study, $12 P$. aeruginosa strains were collected from burn wounds, cultured on special media and then confirmed by differential tests. The PCR test was performed to detect the lasl and las $R$ genes. The expression level of las/ gene was assessed in the presence of garlic extract and tobramycin antibiotic by real-time PCR, and the active ingredient of garlic extract was analyzed by HPLC.

Results: Examination of 12 strains cultured on special and differential media showed that all 12 strains were $P$. aeruginosa. The PCR results indicated that all strains had $100 \%$ las I and las $R$ genes. The real-time PCR results also revealed that the garlic extract was able to reduce the expression level of lasl gene in $P$. aeruginosa. It was found that tobramycin has a greater ability to reduce the expression level of this gene compared with garlic extract.

Conclusion: This study showed that the garlic extract could reduce the expression of las/ gene in $P$. aeruginosa isolates, and that the active ingredients of this extract could be used to treat infections as an alternative to antibiotic therapy.

Keywords: Pseudomonas aeruginosa, Garlic extract, Tobramycin, Quorum Sensing

$$
\text { Received: 2020/08/09; Accepted: 2020/10/13; Published Online: 2021/01/10 }
$$

Soheila Moradi Bidhendi, Associate Professor, Razi Vaccine and Serum Research Institute, Agricultural

Corresponding Information: $\quad$ Research, Education and Extension Organization, Tehran, Iran Email: $\underline{\text { s.moradibidhendi@yahoo.com }}$

(c) (i) (5) Copyright ( $)$ 2021, This is an original open-access article distributed under the terms of the Creative Commons Attribution-noncommercial 4.0 International License which
permits copy and redistribution of the material just in noncommercial usages with proper citation.

Use your device to scan and read the article online

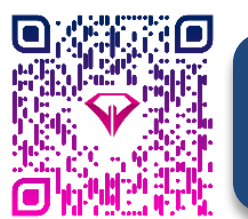

Ghods Zadeh M, Moradi Bidhendi S, Ashrafi F. Comparative Study of Garlic Extract Effect on the Expression of Genes Involved in Quorum Sensing in Pseudomonas aeruginosa and the Antibiotic Tobramycin. Iran J Med Microbiol. 2021; 15 (1):107-120

\section{Download citation: BibTeX | RIS | EndNote | Medlars | ProCite | Reference Manager | RefWorks Send citation to: $\otimes_{\text {Mendeley }} 2$ zotero $\underline{\underline{H}}$ RefWorks}

\section{Introduction}

Identifying the bacterial cell-to-cell communication led to an understanding of the fact that interdependent functions are not limited to eukaryotic organisms and can also be present in bacteria. The process of cell-to-cell coordination and communication that involves the production of extracellular and diffuse molecules, followed by the regulation of gene expression, is called quorum sensing (QS) (1). The QS is a process that has changed our view of the life cycle of bacteria, meaning that the bacteria were considered sporadic organisms in the past, and they were believed to ensure their survival 
through adaptation to environmental conditions without any communication. However, researchers have now discovered the bacterial cell-to-cell communication, signaling and interaction through the information exchange. Therefore, it is concluded that the presence of a signaling network in bacteria is a complex and necessary aspect in their lives (2).

The study of cell-to-cell communication and its effects on the transcription of the unicellular organism has a variety of practical applications. One of them is the possibility of interfering with cell-to-cell communication systems in pathogenic microbes. The QS is a way for bacterial cell-to-cell signaling and exchange information between two partners; the sender and receiver of a communication molecule benefit from the process (3). In bacteria, the QS system regulates phenotypes covering bioluminescence, the production of exoplysaccharides, virulence, conjugative transfer of plasmids, the production of antibiotics and exoenzymes, the formation of biofilms, and the inhibition of growth. Types of molecules involved in communication include acyl homoserine lactones $(\mathrm{AHL})$, autoinducer2 (AI2), and modified oligopeptides (4).

Pseudomonas aeruginosa is an opportunistic and gram-negative human pathogen. These bacteria develop urinary tract infections, respiratory tract infections, skin inflammation and edema, soft tissue infections, bacteremia, bone and joint infections, stomach and intestinal infections, various systemic infections, especially in patients with severe burns, cancer and AIDS having experienced immunosuppression (5). Disruption of the QS system of $P$. aeruginosa has been shown to eliminate pathogenesis.

Since plants and fungi have had symbiosis with bacteria for millions of years, various mechanisms and substances may have been developed to inhibit the QS system during evolution (6). Garlic is one of the oldest plants whose medicinal effects have long been reported. Garlic has antibacterial effect due to various substances such as alliin, ahoin, allicin and allistain and therefore is consumed against gram-positive and gramnegative bacteria, fungi, parasites and viruses (7).

Since medicinal plants have been used for many years and due to the importance of $P$. aeruginosa as well as the properties of garlic, the present study aimed to investigate the effect of garlic extract on the QS system of this bacterium in order to use this extract in therapeutic process if there is any inhibition of cellto-cell communication.

\section{Materials and Methods}

Sample Collection: In the present descriptiveanalytical cross-sectional study, 12 samples of Pseudomonas were collected from burn wounds of hospitalized patients. The samples were transferred to the laboratory, cultured on the Blood Agar, Eosin Methylene Blue (EMB) and Mueller Hinton Agar (MHA) culture media and then tested morphologically and biochemically.

\section{Identification of Isolates}

Colonies were confirmed using standard biochemical and microbiological tests, including gram staining, oxidase, catalase, motility, citrate, TSI, indole, Methyl Red-Voges Proskauer (MR-VP), urease, oxidation-fermentation (OF), growth at $42^{\circ} \mathrm{C}$ and pigment formation on Cetrimide Agar medium, and based on the Bergey's manual of determinative bacteriology; all isolates were confirmed as $P$. aeruginosa (8).

\section{DNA Extraction}

The genomic DNA of the isolates was extracted using the GTP kit (Gene Transfer Pioneers, Iran). To this end, 1 to $2 \mathrm{~mL}$ of bacterial suspension cultured on EMB equivalent to $0.5 \mathrm{McF}$ arland turbidity standard was used for extraction according to the manufacturer's instructions. The extracted DNA stocks were stored at $-20 \circ C$. The quantity and quality of the extracted DNA were examined using spectrophotometer (flow meter E6150) and agarose gel electrophoresis, respectively.

PCR Reaction to Detect the Presence of IasI, IasR and rpoD Genes

The PCR reaction was performed on a final volume of $20 \mu \mathrm{L}$ containing $3 \mu \mathrm{m}$ of DNA pattern (200 ng), 10 pmol of each primer $(1 \mu \mathrm{L}), 1 \mu \mathrm{L}$ of distilled water, and $10 \mu \mathrm{m}$ of $2 x$ Master Mix (Amplicon). The PCR temperature program included the initial denaturation at 95 ㅇ $\mathrm{C}$ for 3 minutes and the 35 cycle with the denaturation at $950 \mathrm{C}$ for 30 seconds, the annealing at $55^{\circ} \mathrm{C}$ for 1 minute and the extension at $72^{\circ} \mathrm{C}$ for 1 minute and the final extension at $72^{\circ} \mathrm{C}$ for 10 minutes. Finally, the amplified segments were observed using $1.5 \%$ agarose gel electrophoresis and etidium bromide staining. The sequence of primers used is given in Table 1 . The PCR reaction was performed using a thermocycler (BioRad-USA). 
Table 1. Sequence of primers used in this study

\begin{tabular}{|c|c|c|c|}
\hline Primers & Sequence & Length & Reference \\
\hline lasI-F & GCTTCTGCACGGCAAGGA & $63 \mathrm{bp}$ & \multirow{6}{*}{ (9) } \\
\hline lasI-R & ATGGCGAAACGGCTGAGTT & $63 b p$ & \\
\hline rpoD-F & GGGCTGTCTCGAATACGTTGA & $90 \mathrm{bp}$ & \\
\hline rpoD-R & ACCTGCCGGAGGATATTTCC & $90 \mathrm{bp}$ & \\
\hline lasR-F & AAGGAAGTGTTGCAGTGGTG & $68 \mathrm{bp}$ & \\
\hline lasR-R & GAGCAGTTGCAGATAACCGA & $68 \mathrm{bp}$ & \\
\hline
\end{tabular}

\section{Preparation of Garlic Extraction}

After peeling garlic cloves, $125 \mathrm{~g}$ of garlic was crushed using a blender and then mixed with 2 liters of $70 \%$ formalin and shaken on the rotator for 48 hours. The resulting mixture was passed through sterile gauze and Whatman filter paper, and the resulting material was centrifuged by a refrigerated centrifuge at $5000 \mathrm{rpm}$ for 30 minutes. Other waste products, such as cellulose and cell shells were removed from the extract and a clear yellowish solution was obtained, distilled for concentration, and stored at 4 으 for subsequent testing.

\section{HPLC Test}

In this study, HPLC purification was used to purify the compounds in the immunomodulator fraction of garlic extract and to establish a suitable system for further production of immunomodulators in a shorter time for clinical trials and pharmacological examinations. The fractions collected from the filtration were separated by reversed-phase HPLC on TPV10 208 Vydac C8 reversed-phase preparative column $(1 * 25 \mathrm{~cm})$. Purification was performed with $0.1 \%$ TFA solution in water and $0.09 \%$ TFA solution in acetonitrile and with a flow rate of $1 \mathrm{ml} / \mathrm{min}$ from $0 \%$ to $15 \%$ TFA solutions for 60 minutes. Optical density (OD) was read at the wavelengths of 215, 254 and 280 $\mathrm{nm}$.

\section{Determination of the MIC Value using Broth Dilution Method}

The minimum inhibitory concentration (MIC) was determined for each of the bacteria in the exposure to the garlic extract and the tobramycin antibiotic using the standard method proposed by the Clinical and Laboratory Standards Institute (CLSI). The method used a standard 96-well microplate, each containing $100 \mu \mathrm{L}$ of the Mueller Hinton Broth (MHB) medium. To determine the MIC value, the dilution of garlic extract was started from $2048 \mu \mathrm{g} / \mathrm{mL}$, and $100 \mu \mathrm{L}$ were added to the first well and then pipetted into the lower wells, and the concentration dropped to the next wells. Next, $100 \mu \mathrm{L}$ of bacterial suspension equivalent to 0.5 McFarland turbidity standard was poured into all wells. To determine the MIC value for the tobramycin antibiotic, the dilution was started from $32 \mu \mathrm{g} / \mathrm{mL}$. In all wells, $100 \mu \mathrm{L}$ of MHB medium was poured and subsequently the first well was added by the antibiotic stock and pipetted to the next wells. After that, $100 \mu \mathrm{L}$ of microbial suspension equivalent to $0.5 \mathrm{McF}$ arland turbidity standard was added to all wells. In addition, two rows of wells were used as positive control (medium + microbial suspension) and negative control (medium + garlic extract/antibiotic). The microplates were incubated at $37^{\circ} \mathrm{C}$ for 24 hours. After this period, the first well with the observed growth was considered as the MIC value $(10,11)$.

\section{RNA Extraction}

In order to investigate the expression of las/ gene using $r p o D$ reference gene, the RNA of Pseudomonas treated with garlic extract and tobramycin antibiotic according to MIC value and also untreated Pseudomonas was extracted using Cinna Pure-RNA kit (CinnaGen, Cat. No. PR891620, Iran). Quantus ${ }^{\mathrm{TM}}$ Fluorometer (Cat.\# E6150) and Promega kit were used to quantify the RNA extracted.

\section{Construction of cDNA}

To this end, $1 \mu \mathrm{g}$ of RNA was mixed with $1 \mu \mathrm{L}$ of enzyme buffer, $1 \mu \mathrm{L}$ of DNase enzyme and $0.5 \mu \mathrm{l}$ of RNase inhibitor, respectively, and then reaching final volume of $10 \mu \mathrm{L}$ with RNase-free water. The microtubes were incubated at $37^{\circ} \mathrm{C}$ for $30 \mathrm{~min}$ and 1 $\mu \mathrm{L}$ of EDTA $0.5 \mathrm{M}$ was added to each. The incubation was performed for $10 \mathrm{~min}$ at $65^{\circ} \mathrm{C}$ to inactivate the DNase enzyme; $0.5 \mu \mathrm{L}$ of random hexamer and $0.5 \mu \mathrm{L}$ of Oligo (dT) were added to the microtubes and incubated at $65^{\circ} \mathrm{C}$ for $5 \mathrm{~min}$. After this time, the microtubes were transferred onto the ice and $13 \mu \mathrm{L}$ of this MasterMix was added to each. The microtubes were incubated at $25^{\circ} \mathrm{C}$ for $5 \mathrm{~min}$, at $42^{\circ} \mathrm{C}$ for $60 \mathrm{~min}$, and at $70^{\circ} \mathrm{C}$ for $10 \mathrm{~min}$. The resulting single-stranded cDNA was stored at $-20^{\circ} \mathrm{C}$. The used MasterMix contained $1 \mu \mathrm{L}$ of dNTP, $4 \mu \mathrm{L}$ of RT buffer, $2 \mu \mathrm{L}$ of RT enzyme, $0.5 \mu \mathrm{L}$ of RNase inhibitor and $5.5 \mu \mathrm{L}$ of RNasefree water.

\section{Real-time PCR Process}

To perform the real-time PCR process, $10 \mu \mathrm{L}$ of PCR MasterMix, $1 \mu \mathrm{L}$ of each of the forward and reverse primers (Table 1), $1.5 \mu \mathrm{L}$ of constructed cDNA and 5.6 $\mu \mathrm{L}$ of water were mixed in a microtube. Samples were placed in the device with a temperature program 
including 10 minutes of initial denaturation at $94{ }^{\circ} \mathrm{C}, 15$ seconds at $94{ }^{\circ} \mathrm{C}, 25$ seconds at $55^{\circ} \mathrm{C}$ and 35 seconds at $72^{\circ} \mathrm{C}$.

\section{Real-time PCR Data Analysis}

The real-time $P C R$ data were analyzed by the software available in the one plusABI device using the $-\Delta \Delta C T$ method, and the final number $\left(2^{-\Delta \Delta C T}\right)$ obtained from various repeats was statistically analyzed using the GenEX software

\section{RESULTS}

HPLC test: Evaluation of garlic extract using HPLC method and analysis of the resulting chromatogram showed that the highest compound in the extract is allicin. This study was compared with the internal standard (Figure 1).

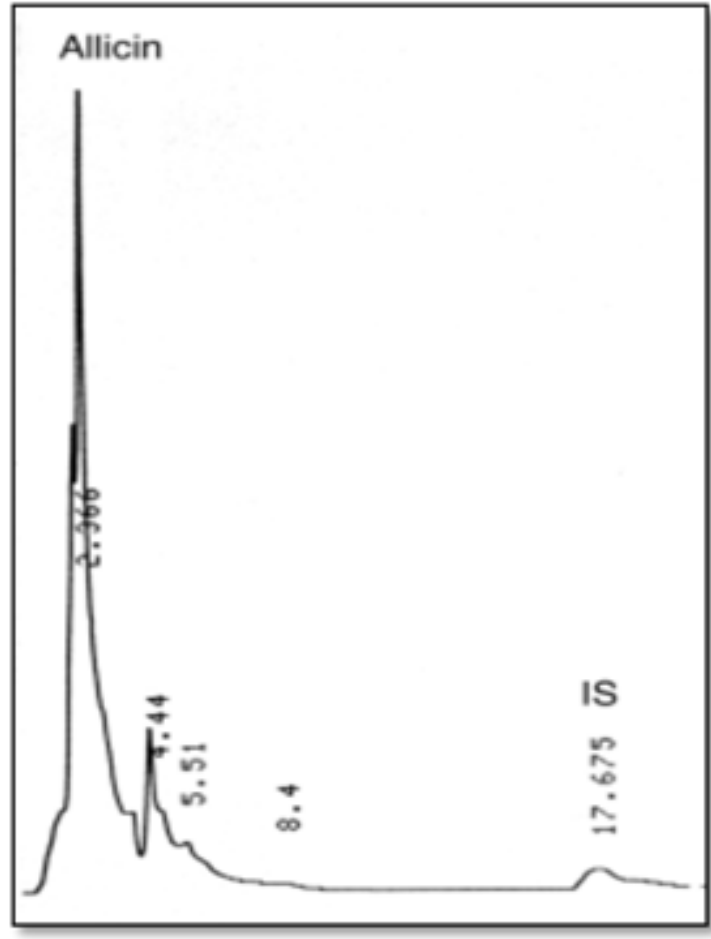

Figure 1- HPLC chromatogram for allicin and internal standard (IS 2.7.4. Polymeric nanoparticles

\section{MIC Determination}

After 24 hours of incubation at $37{ }^{\circ} \mathrm{C}$, the sub-MIC value was determined to be $256 \mu \mathrm{g} / \mathrm{mL}$ for garlic extract and $16 \mu \mathrm{g} / \mathrm{mL}$ for tobramycin.

\section{Investigating the Presence of lasl, lasR and rpoD Genes}

The results of PCR molecular analysis for the lasl, lasR and $r p o D$ genes of QS system were obtained on the basis of band observation in the mentioned region on $1 \%$ agarose gel. In the present study, all $12(100 \%)$ samples of
P. aeruginosa isolated from clinical samples had these genes (Figures 2 and 3).

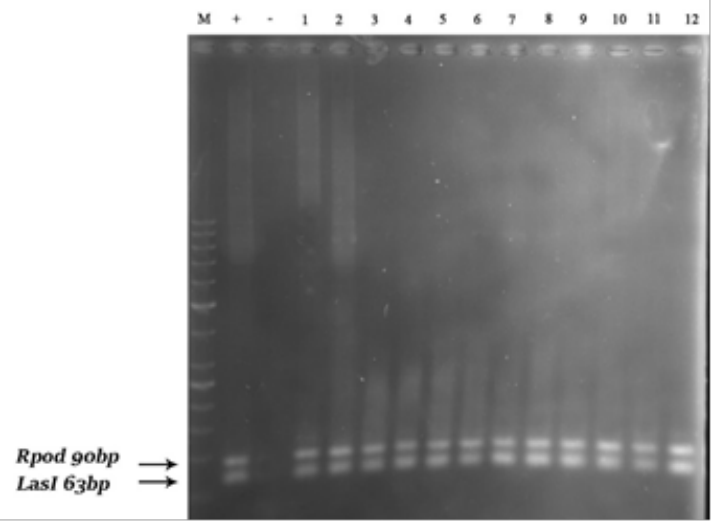

Figure 2. PCR test results for las/ and $r p o D$ genes on a number of strains; left to right, respectively: 100-bp DNA marker plus, positive (+) control, negative (-) control, samples

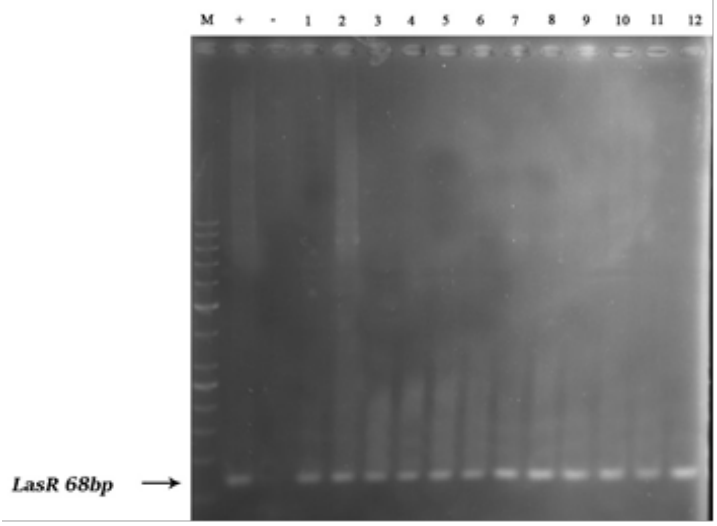

Figure 3- PCR test results for lasR gene on a number of strains; left to right, respectively: 100-bp DNA marker pluse, positive (+) control, negative (-) control, samples

\section{Analysis of Gene Expression}

The real-time PCR technique was used to determine the rate of suppression of gene expression quantitatively in the presence of garlic extract and tobramycin. The realtime PCR process was performed for the lasl gene using the $r p o D$ reference gene, the results of which are shown in Figures 4 (in the presence of garlic extract) and 5 (in the presence of tobramycin). The results indicated a significant difference in las/ gene expression between the two groups untreated and treated with garlic extract. The fold change rate for the las/ gene was calculated to be -1.19 , indicating that this gene was reduced up to 1.19 times in the group treated with garlic extract compared to the untreated group. The expression of lasl gene in the tobramycintreated group was also significantly reduced. The fold change rate for the lasl gene was calculated to be -1.27 , indicating that the gene in the tobramycin-treated group decreased up to 1.27 times compared to the untreated group. There was no significant difference between the 
effects of garlic extract and tobramycin in terms of their ability to reduce las/ gene expression.

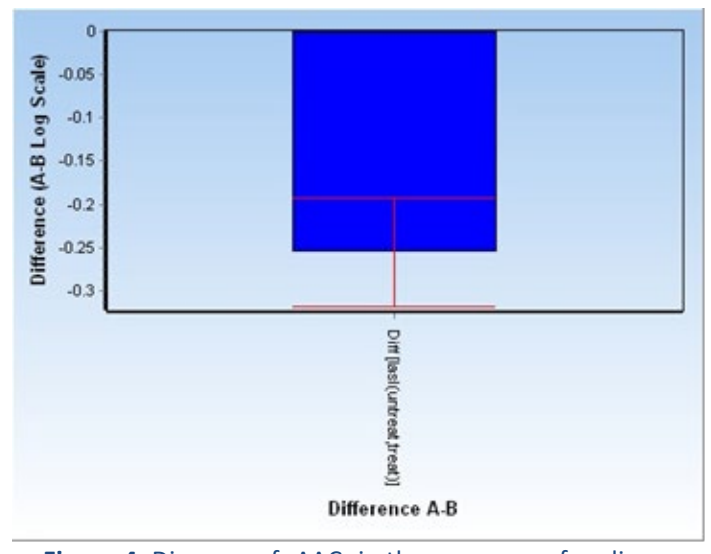

Figure 4. Diagram of $-\Delta \Delta C_{T}$ in the presence of garlic extract

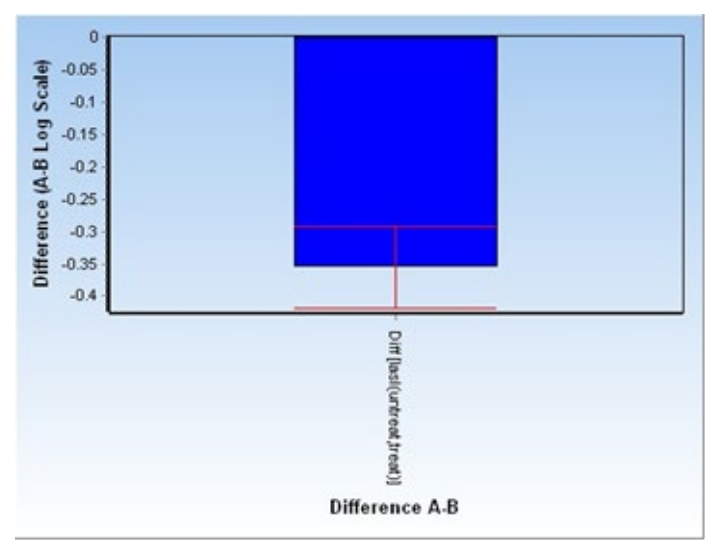

Figure 5. Diagram of $-\Delta \Delta C_{T}$ in the presence of tobramycin antibiotic

\section{Discussion}

The spread of bacterial infections and the development of their antibiotic resistance have prompted researchers to find natural antibacterial compounds. These studies are often performed on various plant compounds, their extracts, and their active compounds (12). The aim of this study was to investigate the effect of garlic extract on $P$. aeruginosa bacteria by evaluating the effect of garlic extract on the expression level of genes affecting bacterial QS system and in comparison with tobramycin antibiotic.

Some garlic compounds include alliin, allicin, organic acids, carbohydrates and vitamins; and the most important properties of garlic are related to allicin (13). The allicin is an essential oil with a bright yellow color and responsible for the specific aroma of garlic. The allicin is also called allicin potential or allicin yield and accounts for the antimicrobial properties of garlic. This compound plays a major part in its antibiotic properties through specific inhibition of acetylcholine A synthase; the inhibition of this enzyme inhibits lipid biosynthesis and fatty acids and ultimately disrupts the bioavailability of microorganisms (14). One of the important features of allicin is its ability to penetrate and pass through membrane phospholipids, which is why it can freely pass through the membrane and perform its functions (15). In the analysis of garlic extract obtained in the present study using HPLC technique, the allicin was the main ingredient in the extract. Therefore, its antimicrobial effects were expected to be observed on $P$. aeruginosa, but the main objective was to evaluate the mechanism of action of this antimicrobial agent and to investigate the expression of QS-related genes and the biofilm formation in the presence of extract.

The lasl and lasR genes are inherently present in the genome structure of most pathogenic $P$. aeruginosa bacteria isolated from medical centers and develop QS system, biofilm and drug resistance in these strains. In the $P$. aeruginosa bacteria, the QS system consists of two gene systems, LasR-Lasl and RhIR-RhlI. The LasI and $R h / l$ genes express acyl-hemoserine lactone (acyl$\mathrm{HSL}$ ) synthase, while the LasR and $R h / R$ genes produce transcriptional regulatory proteins, which bind to their specific signals and activate target (virulence) genes (16). The QS system also exists in other species of Pseudomonas, but the number and sequence of their structural genes varies. Many genes in $P$. aeruginosa are controlled and expressed by $Q S$, which are involved in pathogenesis, including lasl, las $R, r h l l, r h / R$ genes, and controlled genes called las $B, a p r$, and $r h I A B$ in clinical isolates (17).

Plant compounds have been shown to inhibit biofilm formation in a variety of ways. Herbal extracts with bacteriostatic or bactericidal properties inhibit or reduce bacterial biofilm formation. However, some herbal compounds affect biofilm formation without bacteriostatic or bactericidal effects. Their advantage is the failure of bacteria to resist these compounds. For example, some plant compounds interfere with the QS system, which controls bacterial biofilm (18).

The garlic extract stops the QS system and accelerates the elimination of lung infection caused by $P$. aeruginosa. The garlic extract was used to treat lung infections in rats and it was found that the garlic therapy first stimulated higher levels of inflammation and significantly eliminated the pathogenic bacteria (19). Fulghesu et al. (2007) examined different QS inhibitory compounds in $P$. aeruginosa. They tested the inhibitory activity of three macrolide drugs and three lincosamide drugs, resveratrol, garlic extract and $\mathrm{N}$-acetyl cysteine on four strains of $P$. aeruginosa isolated from patients with cystic fibrosis. All of the compounds tested were able to inhibit QS in the tested strains; only lincomycin and $\mathrm{N}$-acetyl cysteine did not inhibit QS in one of the Pseudomonas strains (20). 
In another study, the QS inhibition was investigated using a new genetic system. A set of QS inhibitor screening systems was developed that enabled them to identify a number of new natural and synthetic inhibitors. The two active inhibitors identified in this study were garlic extract and 4-nitropyridine- $\mathrm{N}$-oxide (4-NPO). Transcriptome analysis based on gene arrays showed that 4-NPO and garlic extract were specific for QS-controlling virulence genes in $P$. aeruginosa. The two QS inhibitors also significantly reduced the biofilm resistance of $P$. aeruginosa compared to tobramycin (21). The QS inhibition activity was investigated by garlic extract and QS response reduction was observed in QS receptors of Escherichia coli, Agrobacterium tumefaciens, Chromobacterium violaceum, Pseudomonas putida and Pseudomonas chlororaphis in relation to growth inhibitory effects (22). In addition, the QS inhibition and pathogenesis attenuation of $P$. aeruginosa were investigated under the influence of garlic extract and it has been shown that oral treatment with garlic extract significantly reduces the density of pulmonary bacteria. In vitro experiments also showed that the virulence factors and the formation of $Q S$ signals by the bacterium $P$. aeruginosa decreased in the presence of fresh garlic extract (23).

Accordingly, the effect of garlic extract on the QS system of P. aeruginosa has been proven frequently, but none of the studies mentioned have expressed the mechanism of this effect and examined the expression of QS genes. In the present study, the expression level of las/ gene as one of the important genes in bacterial QS system was determined by real-time PCR technique, the results of which showed that the garlic extract at a concentration of $256 \mu \mathrm{g} / \mathrm{mL}$ (as MIC value) decreases the expression of lasl gene. In order to compare decreasing effect of garlic extract on the expression of these genes with the effect of tobramycin, the expression of lasl gene in the presence of this antibiotic was also investigated, which showed a greater decrease compared to the garlic extract, but not significant. Therefore, the promising results are that the active ingredients of garlic can be extracted and used as adjunctive antibiotic therapy or as an independent treatment in infections. This active ingredient was found to be allicin in the present study. It is recommended that the extracted and purified allicin in future research should be applied as an anti-QS and therefore antibacterial agent for the treatment of Pseudomonas aeruginosa infections.

\section{Conflict of Interest}

The authors declared no conflict of interests 


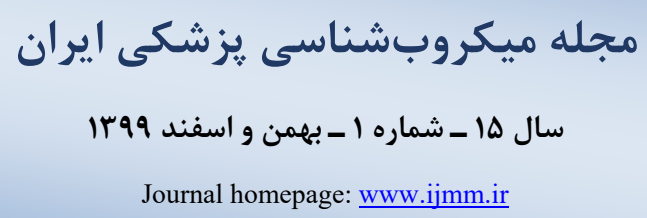

بررسى مقايسهاى بين اثر عصاره سير در بيان ثنهاى دخيل در كروم سنسينَ در باكترى

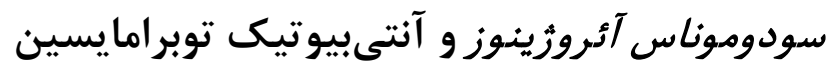

\title{
منصوره قدسزاده'، سهيلا مرادى بيدهندى"'، فاطمه اشرفى"
}

\author{
'. . كارشناسى ارشد ميكروبيولوزى، كروه ميكروبيولوزى، دانشعاه آزاد اسلامى واحد تهران شمال، تهران، ايران

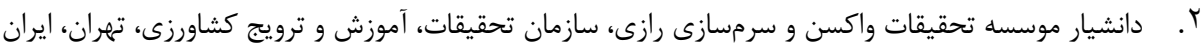

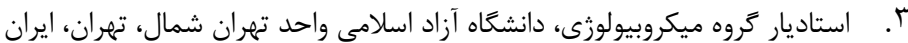

\begin{tabular}{|c|c|}
\hline جكيله & اطلاعات مقاله \\
\hline 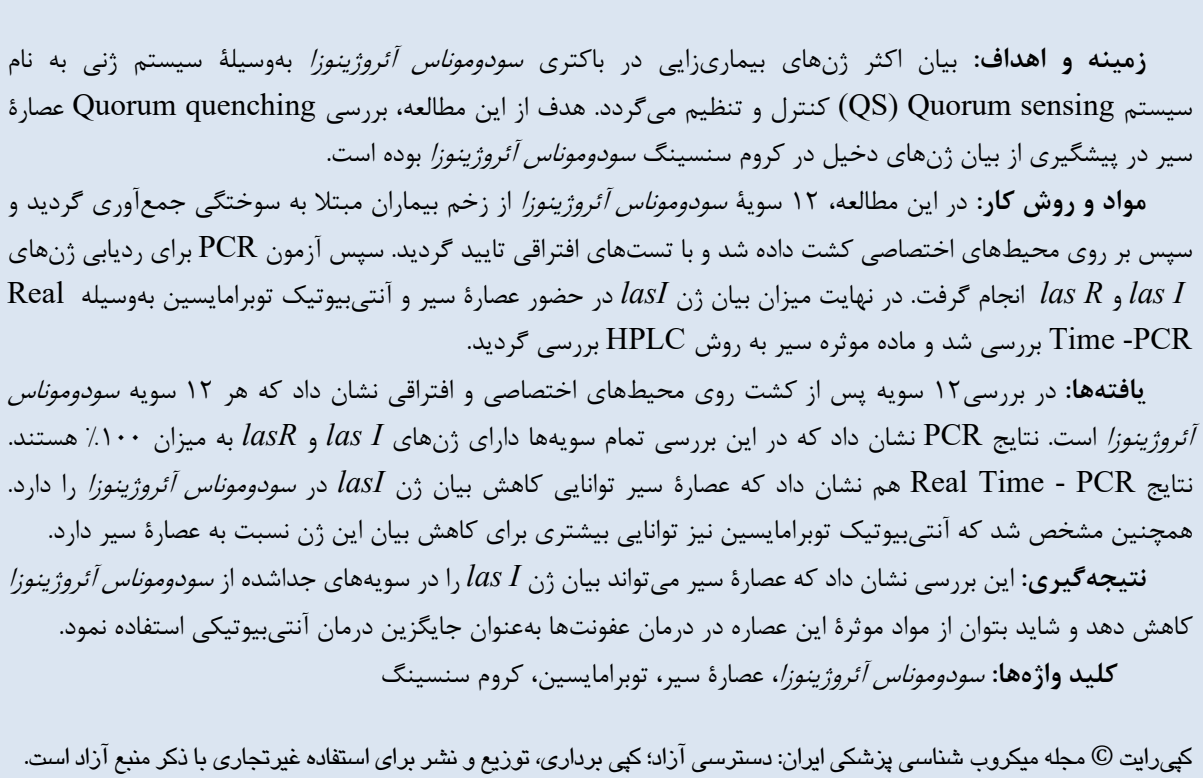 & 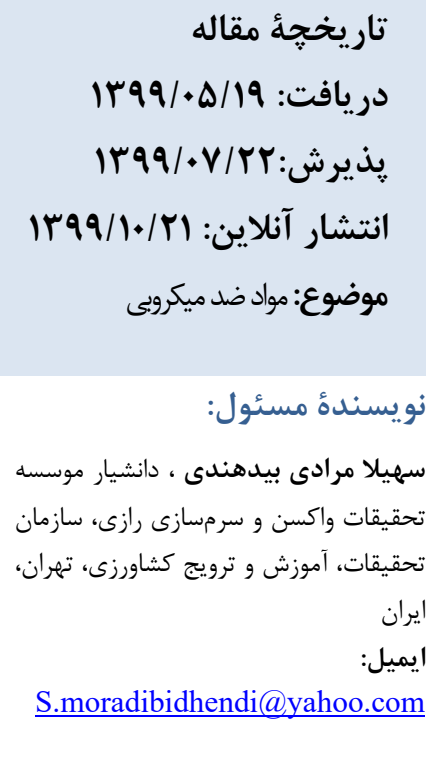 \\
\hline
\end{tabular}

مقدمه

سيگنالينخ و ارتباط سلول به سلول در باكترىها و ميانكنش آنها از

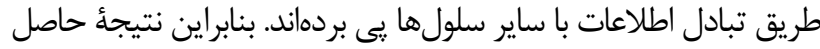

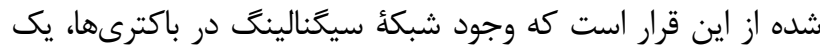

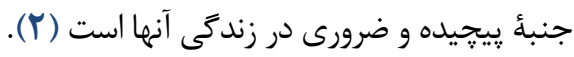
مطالعة ارتباطات سلول به سلول و اثرات آن روى رونويسى اركانيسمهاى تكسلولى كاربردهاى عملى متنوعى دارد. يكى از آنها امكان تداخل با سيستمهاى ارتباطى بين سلولى در ميكروبهاى ياتورن إنى

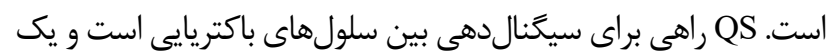
تبادل اطلاعات بين دو شريك است، يعنى فرستنده و كَيرنده يك بكائ

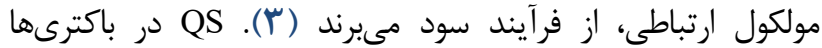

شناسايى ارتباط بين سلولى در ميان باكترىها، منجر به فهم اين واقعيت شد كه عملكردهاى هماهنگ با يكديكر، منحصر به اركانيسمهاى يوكاريوتى نبوده و در باكترىها نيز وجود دارد. به فرآيند

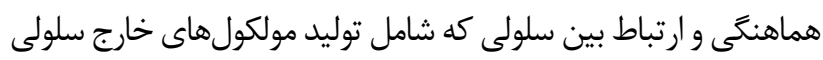
و قابل انتشار و در بى آن تنظيم بيان زنها است، كروم سنسينگ (QS) اطلاق مى گردد (1). كروم سنسينگ فرآيندى است كه ديد ما را نسبت ندان به نحوهُ زندگى باكترىها تغيير داده است. بدين معنى كه در گذششته،

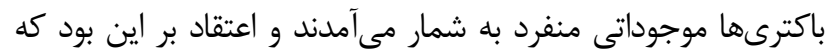
بقاى خود را از طريق سازگار شدن با شرايط محيطى و بدون برقرارى

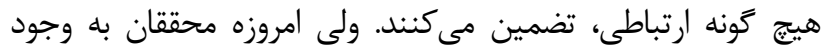


محيط آكار خوندار، محيط EMB، محيط مولر هينتون آكار كشت داده شده و از نظر مورفولوزيك و بيوشيميايى بررسى شدند.

\section{تاييد هويت ايزولهها}

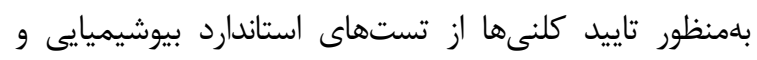

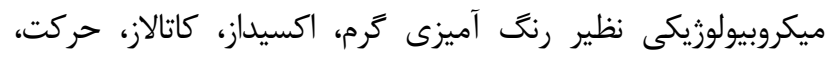

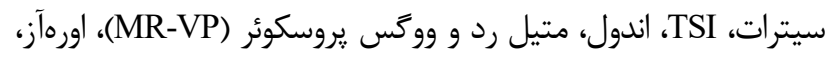

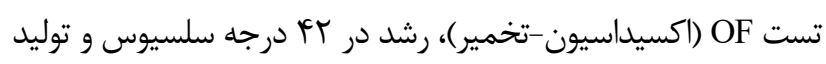
يِيخمان در محيط ستريميد آكار استفاده شد و بر اساس كليد شناسايى

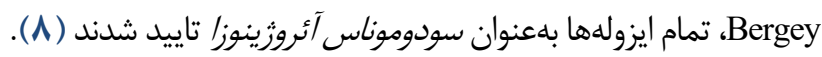

\section{DNA استخراج}

استخراج DNA زنومى ايزولهها با استفاده از كيت GTP (بيشكامان

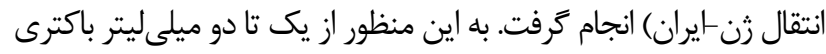

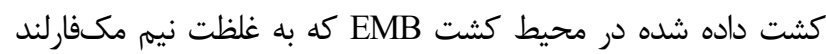
رسيده بود استفاده شد و مراحل استخراج مطابق با دستورالعمل شركت درت سازنده انجام گرفت. استوكهاى DNA استخراج شده، در فريزر در دماى • ץ- درجه سلسيوس نكمهدارى شدند. كميت و كيفيت DNA استخراج شده به ترتيب با استفاده از روشهاى اسيكتروفتومترى (فلورومتر مدل

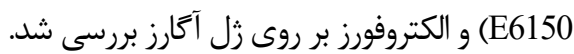

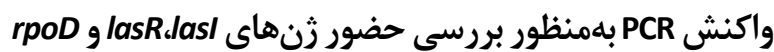

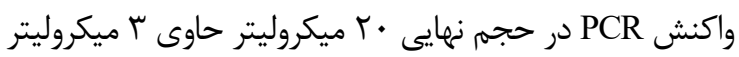

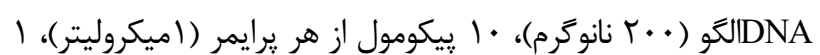

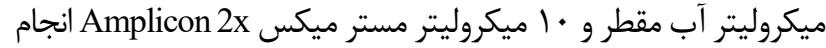
شد. شرايط دمايى PCR شامل مرحله دناتوراسيون اوليه هو درجه

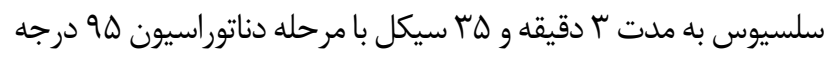

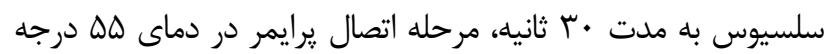

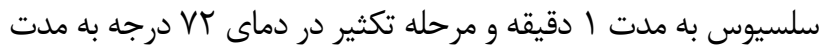

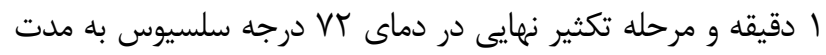
• 1 دقيقه انجام شد. در بايان قطعات تكثير يافته با استفاده از الكتروفورز در زل آكارز ه/ ا درصد و رنغَآميزى با اتيديوم برومايد مشاهده كَرديد.

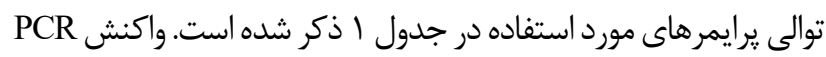
با استفاده از دستخاه ترموسايكلر BioRad-USA انجام كرفت.
فنوتيبهايى را تنظيم مىكند كه شامل بيولومينسانس، توليد

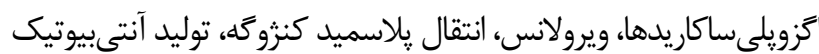

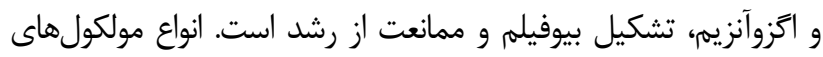
ارتباطى شامل آسيل هموسرين لاكتون (AHL)، مولكولهاى

خودالقاكنندة نوع دو (AI2) و اليكوييتيدهاى تغيير يافته است (F). سودوموناس آئروزينوز/ يك پاتورن انسانى فرصت طلب و كرممنفى است. اين باكترى سبب عفونتهاى مجارى ادرارى، سيستم تنفسى، التهاب و آماس يوست، عفونتهاى بافتهاى نرم، باكتريمى، عفونتهاى استخوان و مفاصل، عفونتهاى معده و رودهها و عفونتهاى

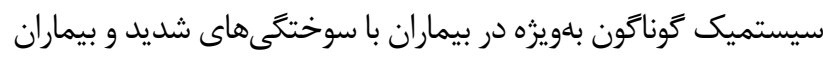
مبتلا به سرطان و ايدز كه سيستم ايمنى آنها سركوب شده است،

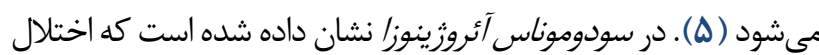

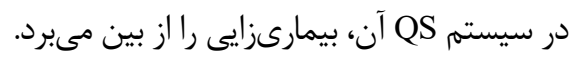
از آنجا كه كياهان و قارجها طى ميليونها سال، از زندكى همزيستى با باكترى ها برخوردار بودهاند، احتمالاً طى تكامل، مكانيسمها

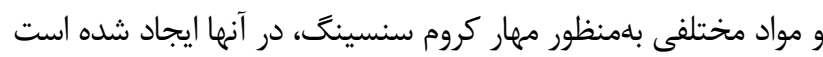

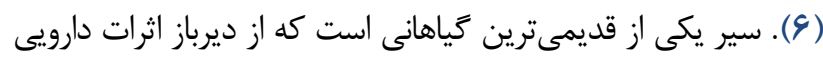
آن كزارش داده شد. اثر ضد باكترى سير به دليل مواد مختلفى مانند

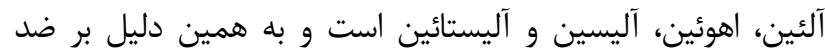

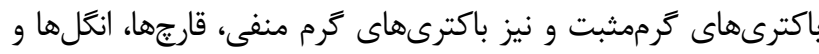

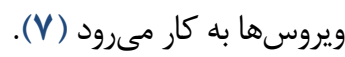

از آنجايى كه سالهاى زيادى است كه از گياهان دارويى استفاده

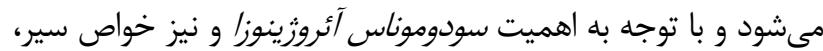

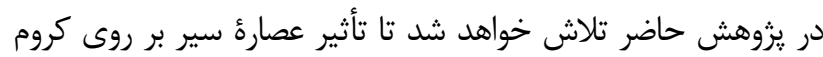

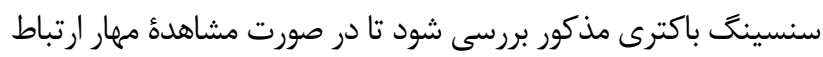
سلولى، از اين عصاره در درمان استفاده كردد.

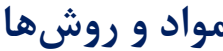

\section{جمع آورى نمونه}

بلمنظور انجام اين مطالعه توصيفى-تحليلى (Cross-Sectional)،

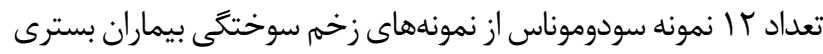

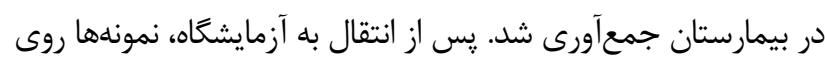
جدول ا. توالى يرايمرهاى مورد استفاده 


\begin{tabular}{|c|c|c|c|}
\hline ن نام برايمر & 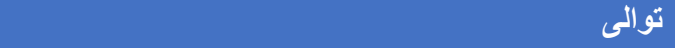 & طول قطعه & رفرنس \\
\hline rpoD-R & ACCTGCCGGAGGATATTTCC & q. bp & \\
\hline lasR-F & AAGGAAGTGTTGCAGTGGTG & \multirow{2}{*}{$9 \wedge \mathrm{bp}$} & \\
\hline lasR-R & GAGCAGTTGCAGATAACCGA & & \\
\hline
\end{tabular}

عصارهزيرى از سير

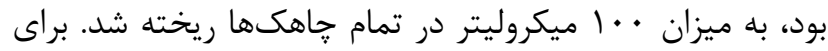

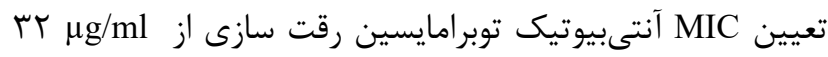

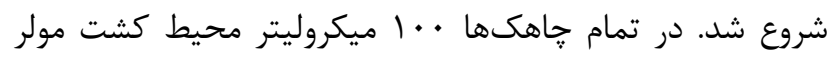

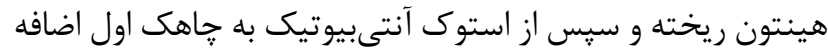

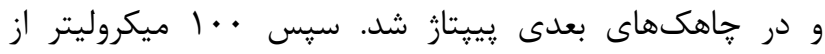

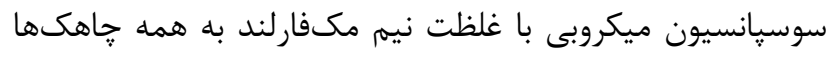

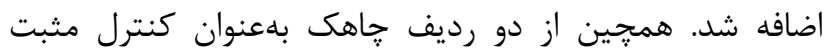

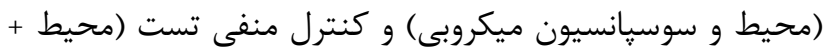

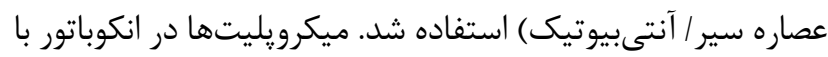

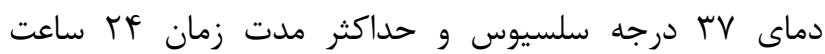

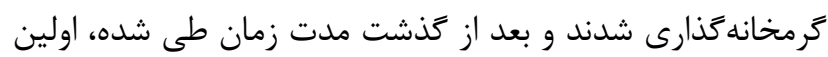

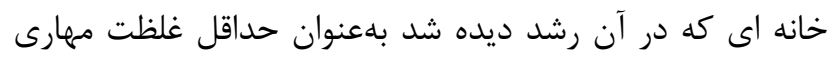

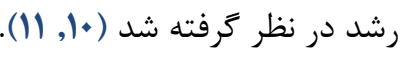

\section{استخراج RNA}

بلهنظور بررسى بيان زن lasI با استفاده از زن مرجع rpoD (بهعنوان

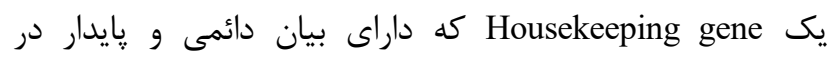

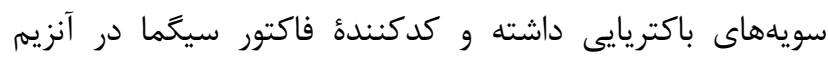

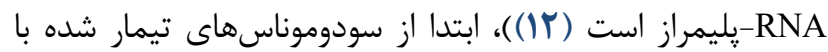

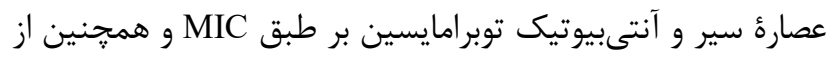

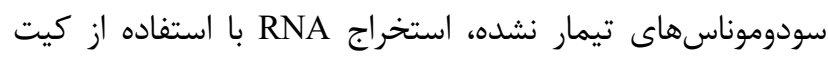

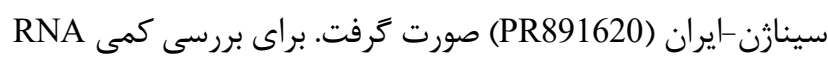

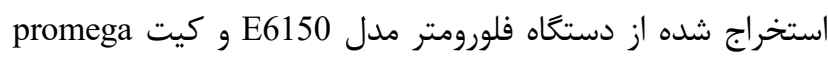

\section{سنتز cDNA}

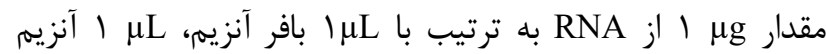

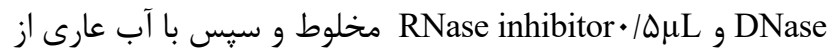

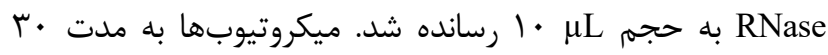

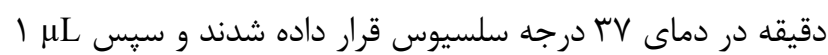

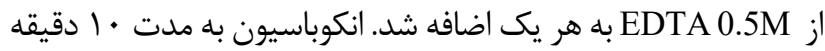
در دماى له درجه سلسيوس بلمنظور غيرفعال شدن آنزيم DNase

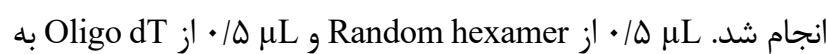

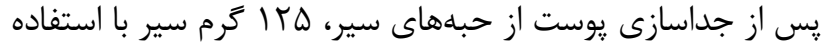

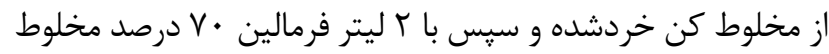

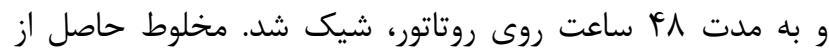
تنطيف استريل و صافى واتمن عبور داده شد و ماده حاصله در

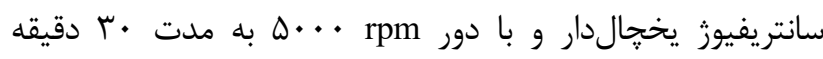
سانتريفيوز گرديد. بدين ترتيب ساير مواد زايد و ناخواسته از جمله بله

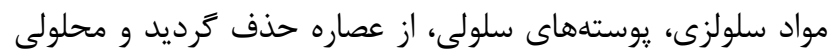

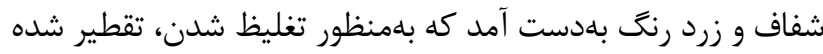
و براى استفادهاى بعدى در دماى أ درجه سلسيوس نكَهدارى شد.

\section{آزمون HPLC}

در اين تحقيق از تخليص به روش HPLC به هدف خالصسازى ازمون

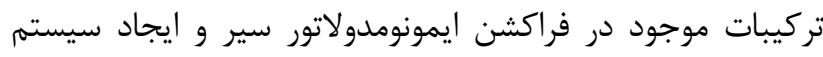

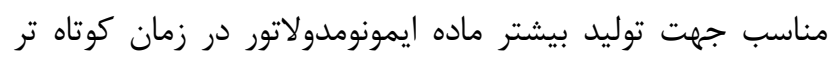
جهت كارآزمايىهاى بالينى و بررسىهاى فارماكولوزيكى استفاده

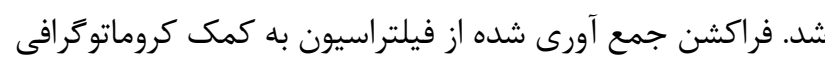
فاز معكوس HPLC روى ستون سمى تياراتيو (1*25 cm)

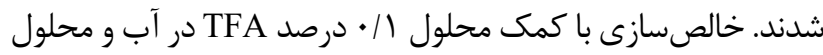

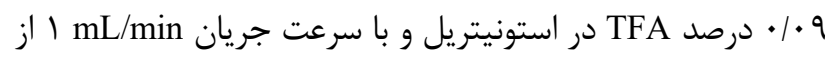

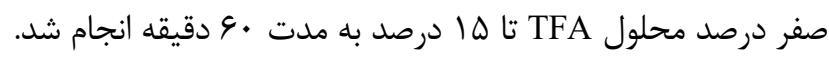

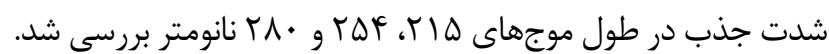

\section{تعيين MIC با روش براث دايلوشن}

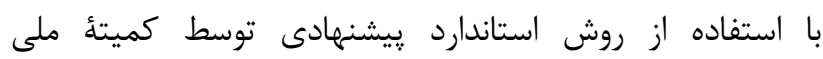
استانداردهاى آزمايشخاههاى بالينى (CLSI)، حداقل غلظت ممانعت

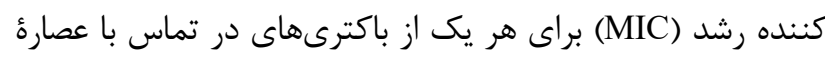

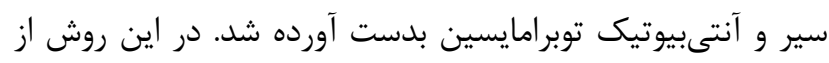

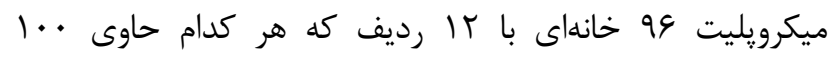
ميكروليتر محيط مولر هينتون براث استريل بود، استفاده كرديد.

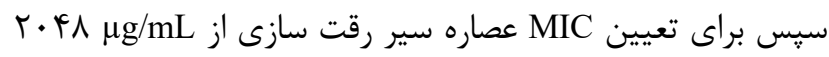

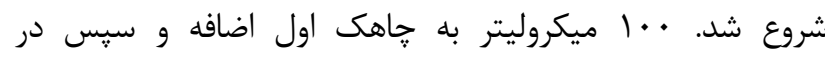

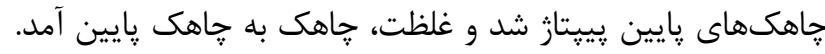

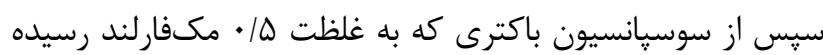




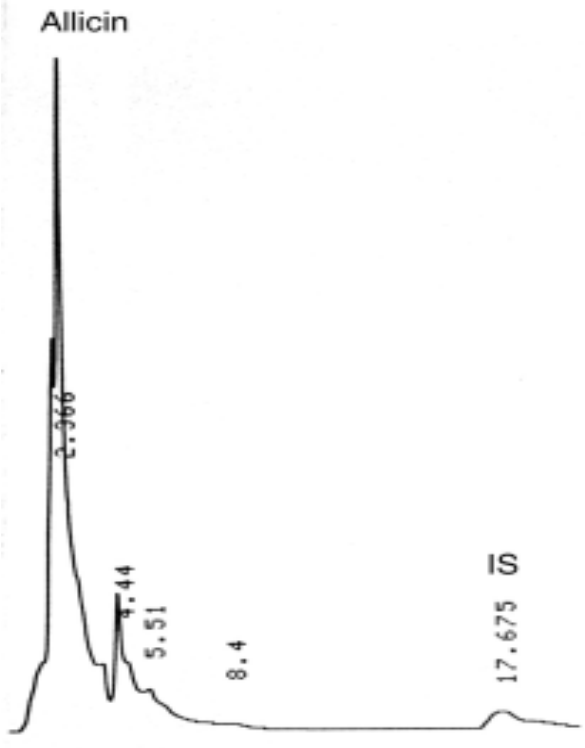

شكل 1. كروماتوكرام HPLC مربوط به آليسين

و استاندارد داخلى (IS)

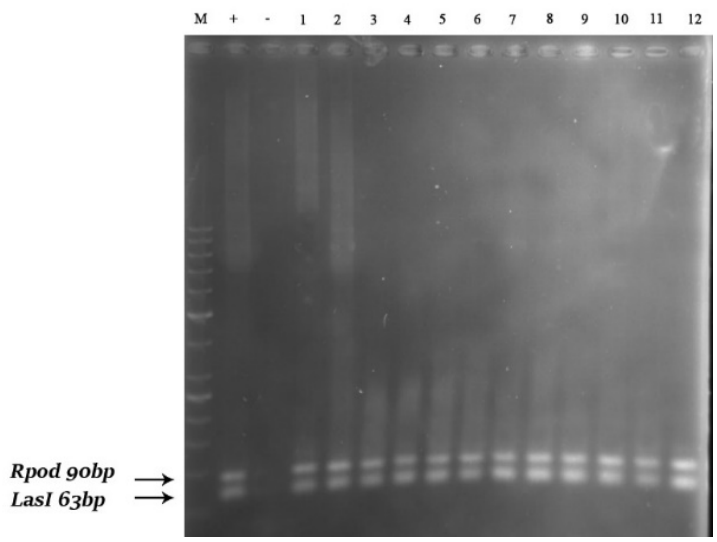

شكل r. نتيجه آزمايش PCR براى رنهاى lasI و rpoD بر روى تعدادى از

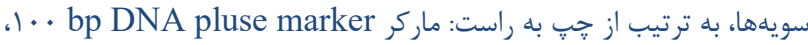
+ كنترل مثبت، - كنترل منفى، نمونهها.

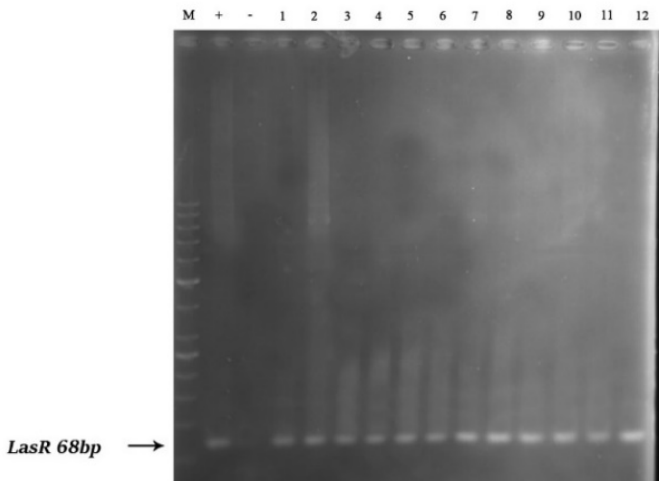

شكل س. نتيجه آزمايش PCR براى زن lasR بر روى تعدادى از سويهها، به

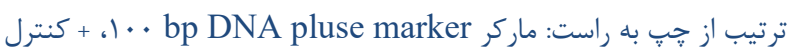

$$
\text { مثبت، - كنترل منفى، نمونهها. }
$$

ميكروتيوبها اضافه شد و به مدت ه دقيقه در دماى له درجه سلسيوس قرار گرفتند. يس از گذشت اين زمان، ميكروتيوبها به

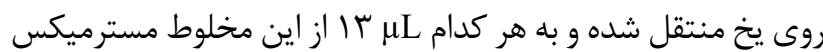

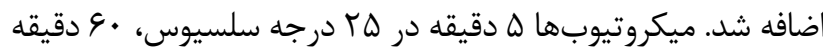
در FT درجه سلسيوس و •l دقيقه در •V درجه سلسيوس قرار كرفتند. cDNA تكرشتهاى حاصل، در دماى • r- درجه سلسيوس درس

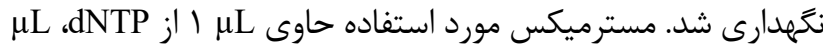

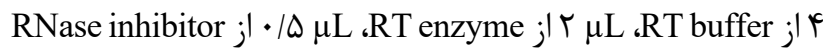
و

واكنش Real Time PCR: منظور انجام واكنش Real time PCR، مقادير مسترميكس PCR PCR I از هر يك از يرايمرهاى فوروارد و ريورس

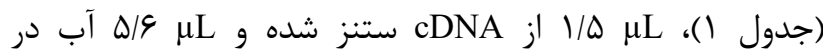
ميكروتيوب مخلوط شدند. نمونهها در دستخاه با برنامه دمايى شامل • ا دقيقه دناتوراسيون اوليه در دماى 9 درجه درجيوس، سلسيوس، ها ثانيه دماى F q درجه سلسيوس، Dr ثانيه دماى DD درجه سلسيوس و

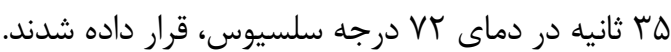

Real-Time آناليز دادههاى one به كمك نرمافزار موجود در دستخاه Real Time PCR دادهاى ABI plus زز تكرارهاى مختلف به كمك نرم افزار genEX تجزيه و تحليل آمارى

شدند.

\section{كافته ها}

آزمون HPLC ارزيابى عصارهٔ تهيه شده از سير با استفاده از روش HPLC و بررسى كروماتوگرام حاصل، نشان دهنده آن بود كه بيشترين تركيب موجود در عصاره، آليسين است. اين بررسى با مقايسه با استاندارد داخلى صورت گرفت (شكل (). تعيين MIC: يس از گذشت زمان عاع ساعت از زمان انكوباسيون در

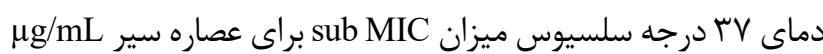

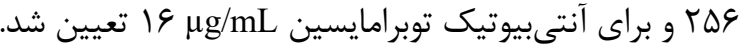

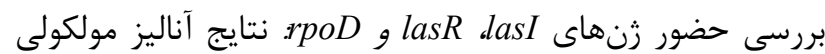

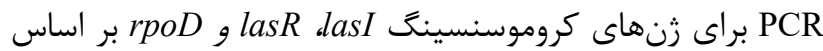
مشاهده باند در ناحيه مذكور بر روى زل آكاروز 1 ٪ بود. در مطالعه

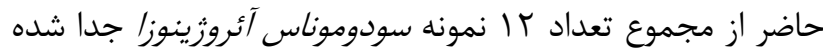

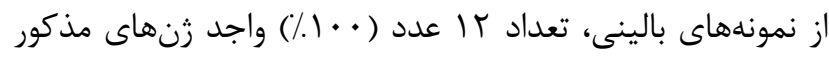

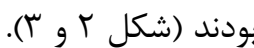




\section{بحث}

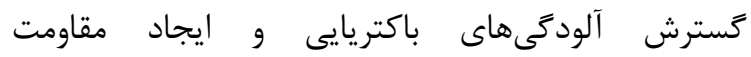
آنتىبيوتيكى در آنها، موجب شده تا تلاش برائ ياى يافتن تركيبات

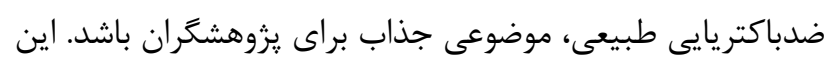

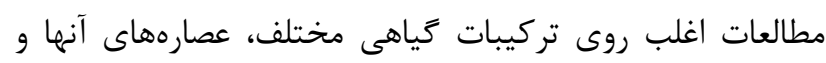

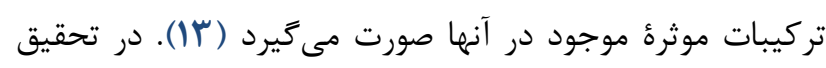

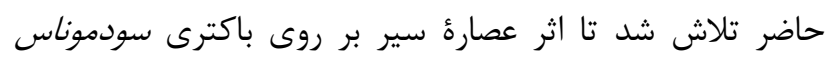

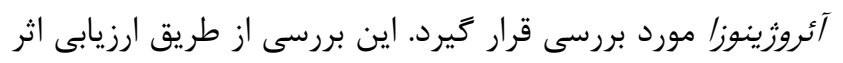

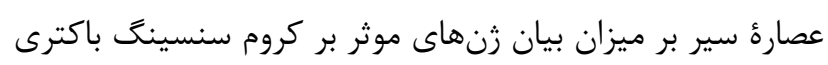

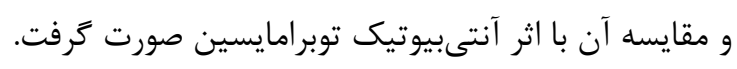
از تركيبات سير، آلئين، آليسين، اسيدهاى آلى، كربوهيدارت

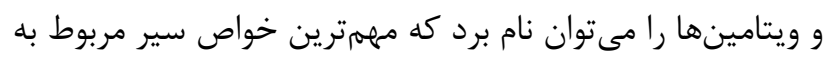

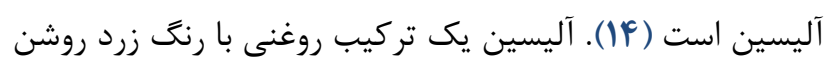

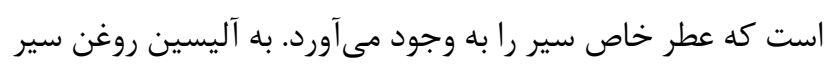

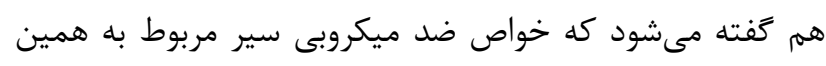

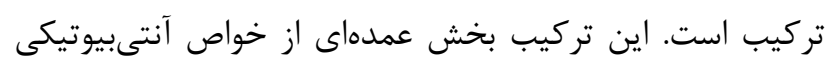

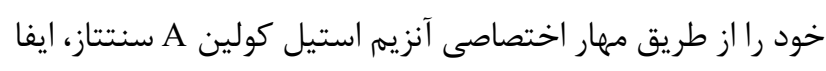

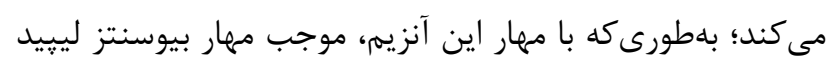

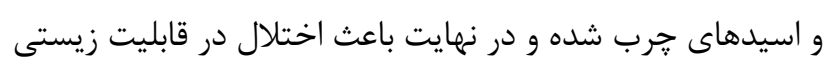

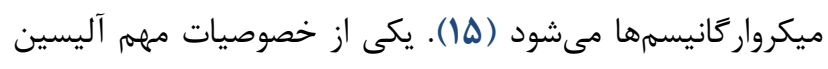

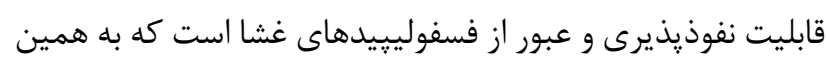

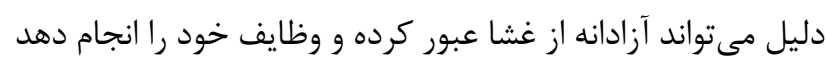

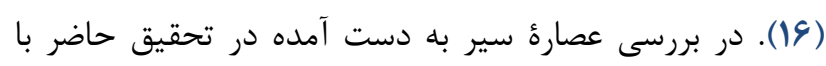

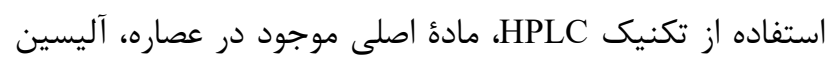

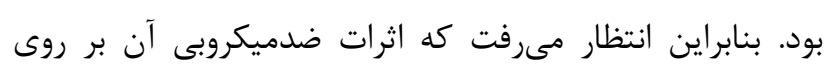

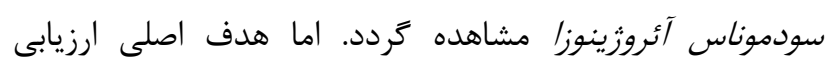

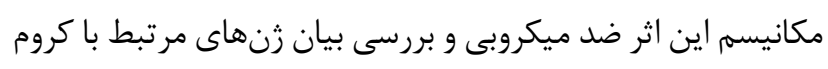

$$
\text { سنسينگ و تشكيل بيوفيلم در حضور عصاره بود. }
$$

زن هاى lasR و ز آن هايى هستند كه در ساختمان زنوم

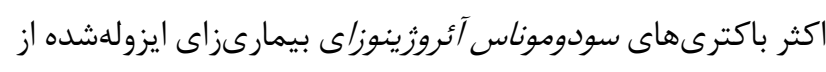

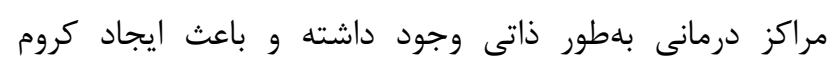

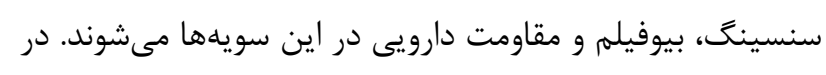

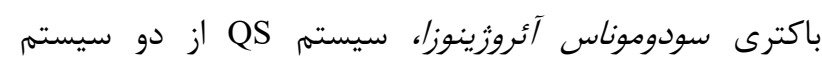

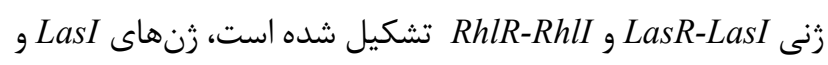
acyl-hemoserine lactone (acyl- بيان كنندة دو آنزئن RhlI

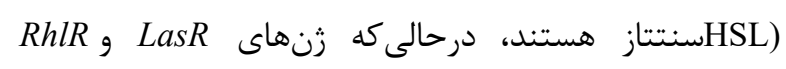
توليدكننده يروتئينهاى تنظيم كننده رونويسى هستند كه بالئ رنسي
بررسى بيان زن: براى تعيين ميزان سركوب بيان زن در حضور

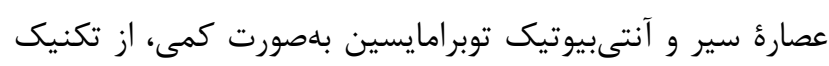
Real-Time PCR و و با استفاده از زن مرجع rposI

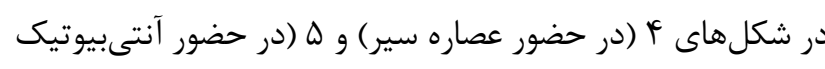

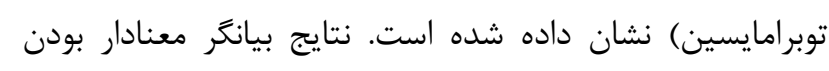

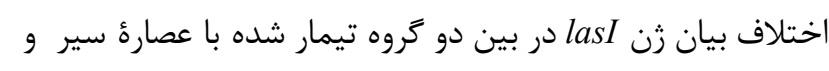

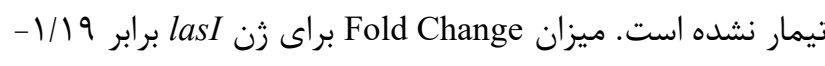

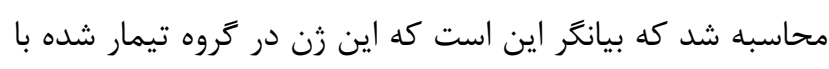
عصاره سير نسبت به كروه غير تيمار شده

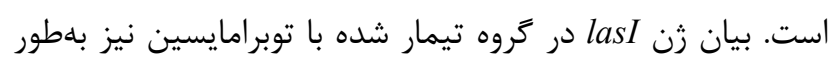

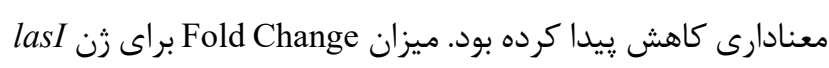

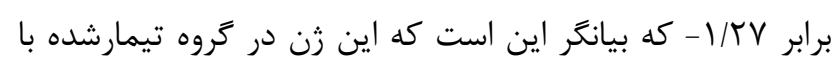

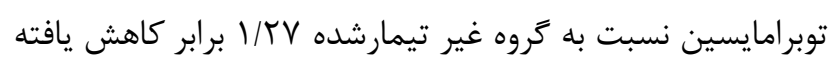

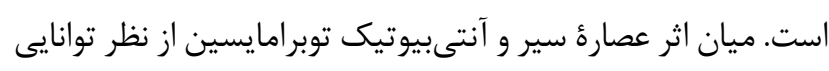

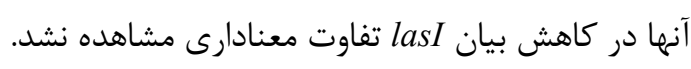

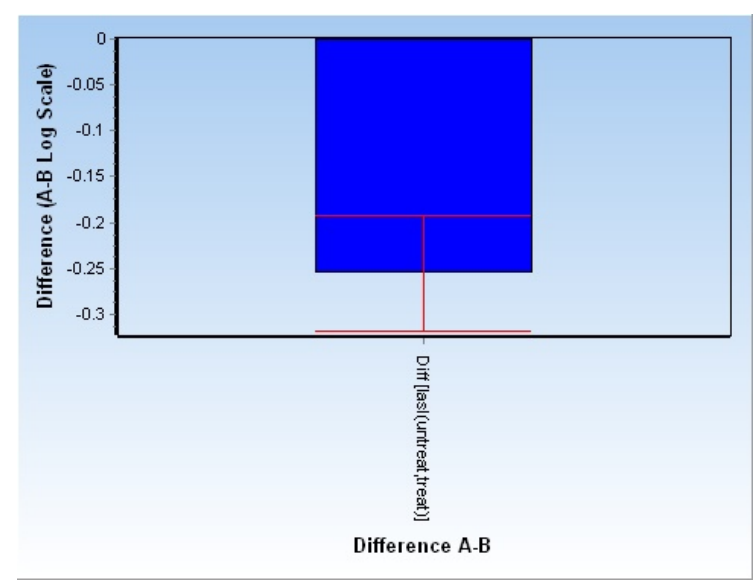

شكل F. نمودار

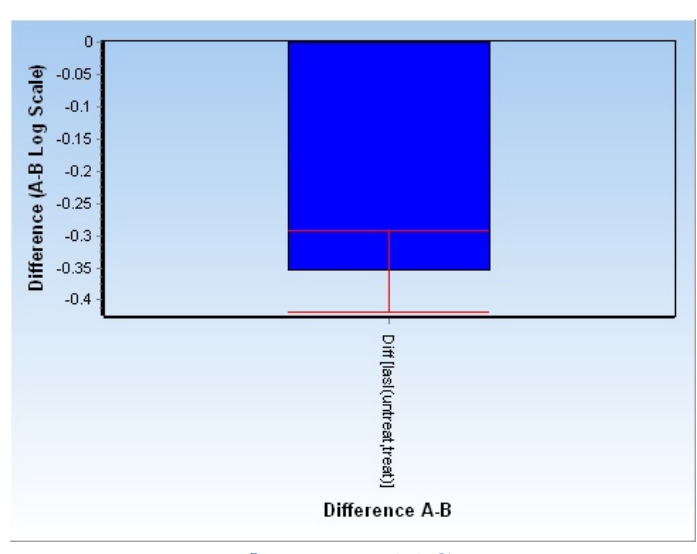

شكل ه. نمودار تغييرات 
براى زنهاى ويرولانس كنترل كنندة كروم سنسينَ در NPO

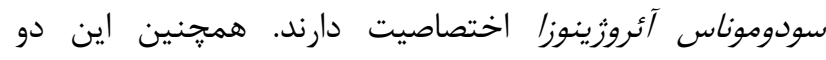
مهار كنندة كروم سنسينگ مقاومت بيوفيلم سودوموناس آئروزينوزا

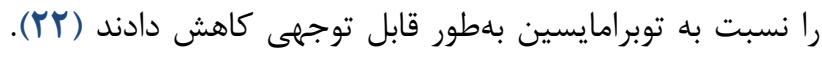

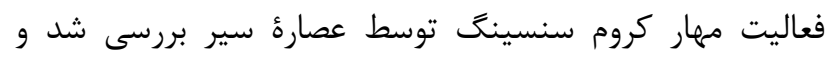

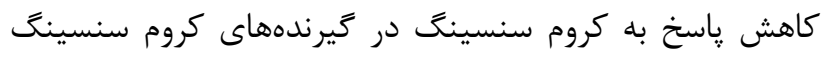

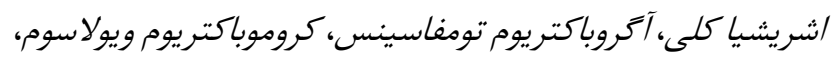

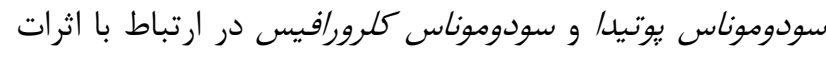

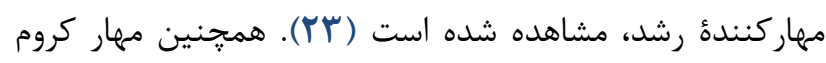

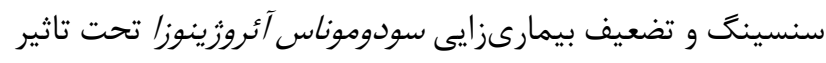

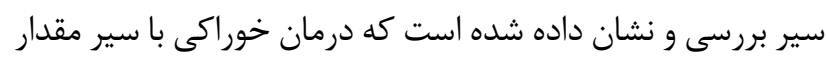
باكترىهاى ريوى را به طور قابل توجهى كاهش مي دهدهد. آزمايشات

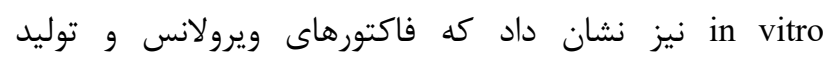

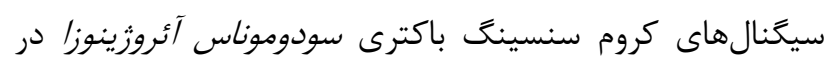

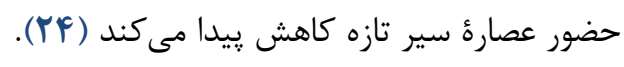

Bjarnsholt

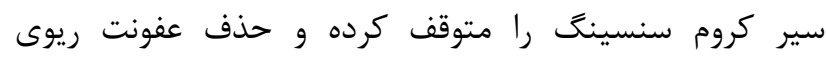

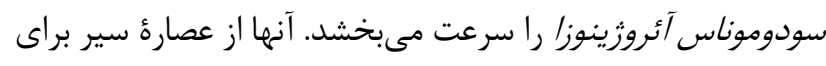

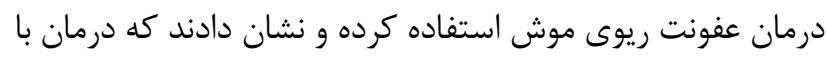

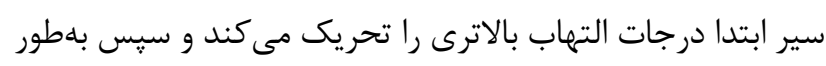
قابل توجهى باكترىهاى عفونى را حذف مى كند (•r). Harjai

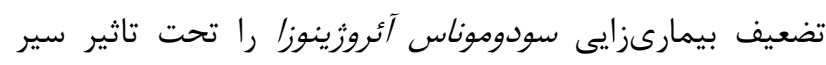

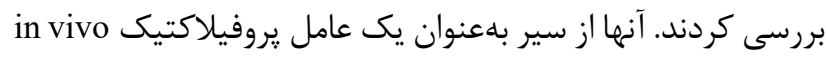

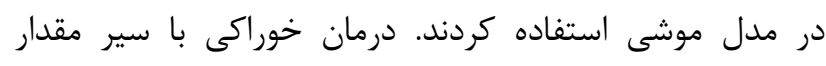

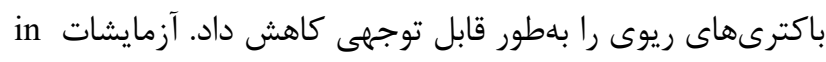

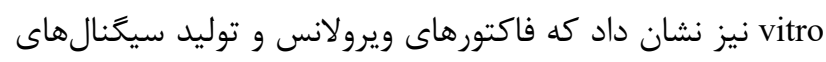

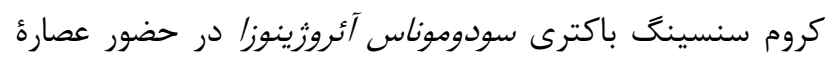

$$
\text { سير تازه كاهش پيدا مى كند (YF). }
$$

Annapoorani مهار كنندههاى كيرنده يروتئينهاى lasR و

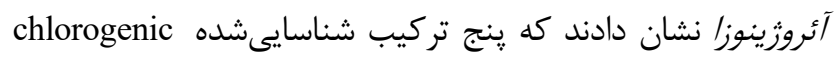
mangiferin rosmarinic acid naringin ،morin ،acid كياهان دارويى طبيعى وجود دارند داراى خاصيت ضد باكتريايى و

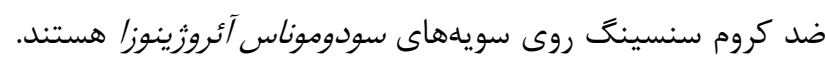

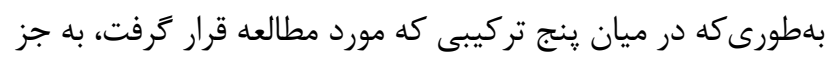
mangiferin
اتصال به سيگنال اختصاصى خود سبب فعالسازى زنهاى هدف

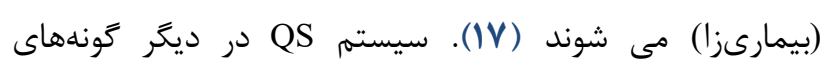

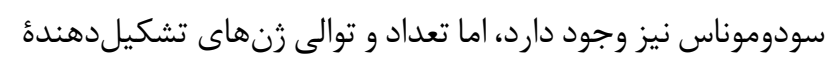

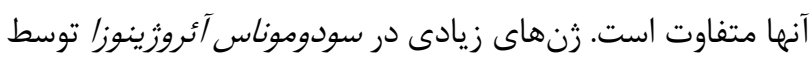

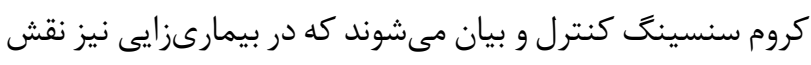

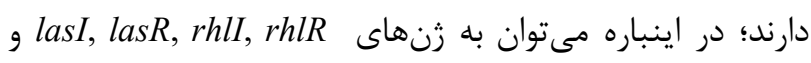

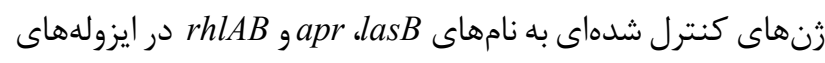

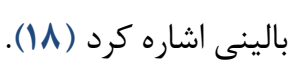

نشان داده شده است كه تركيبات گياهى از راههاى مختلفى

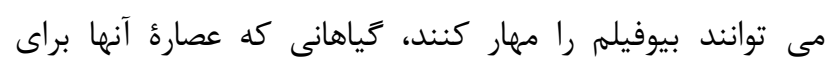
باكترىها خاصيت كشند كى يا مهار كنند

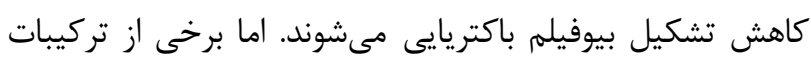

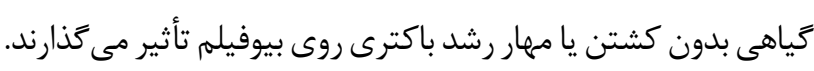

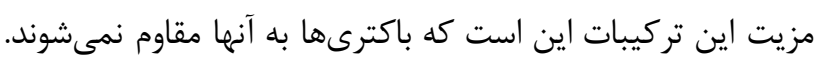

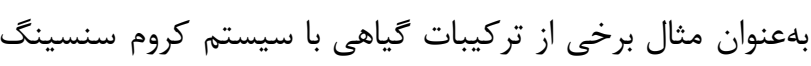
كه بيوفيلم باكتريايى را كنترل مى كند، تداخل ايجاد مى كنند (19). عصارٔ سير كروم سنسينَ را متوقف كرده و حذف عفونت

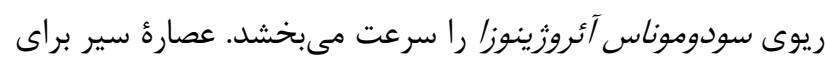

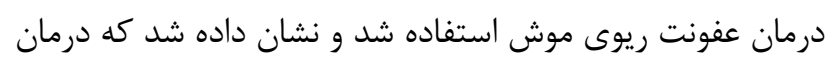

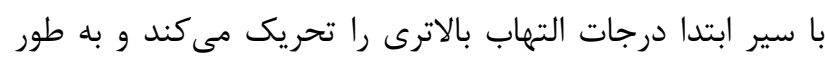

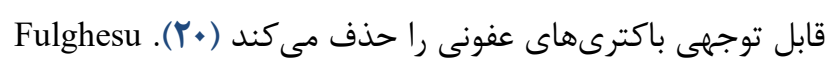

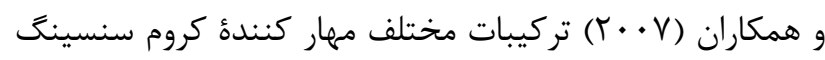

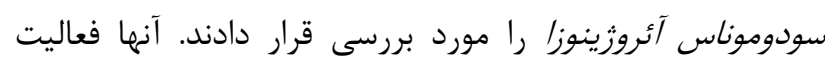
مهارى سه داروى ماكروليد و سه داروى لينكوزاميد، رسوراتول،

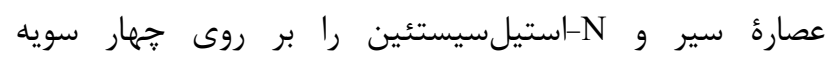

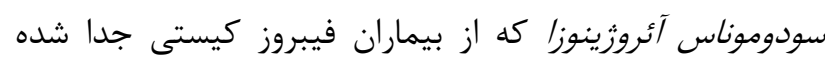

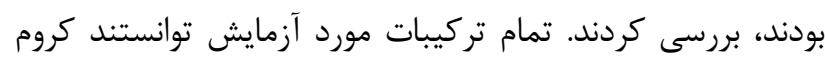

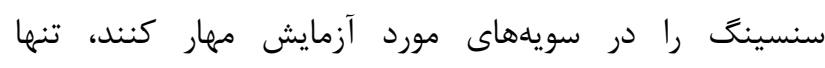

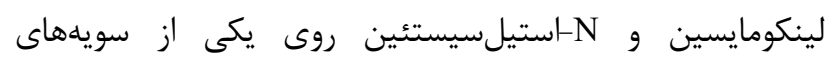

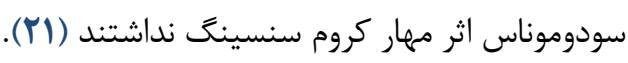

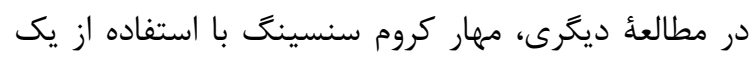

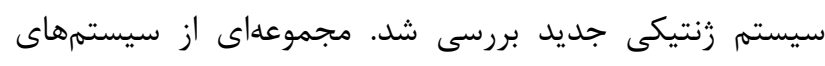

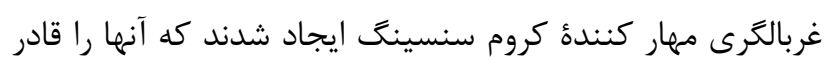

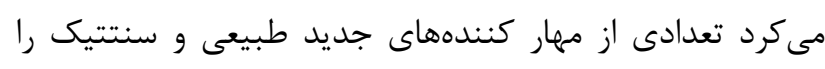

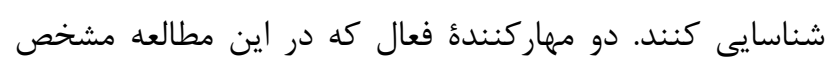

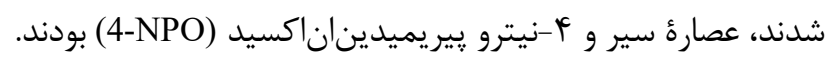

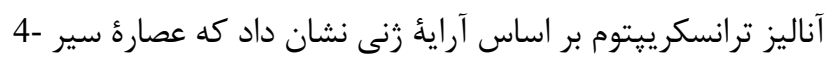


نكرفته است. در مطالعه حاضر ميزان بيان زن lasI بهعنوان يكى از

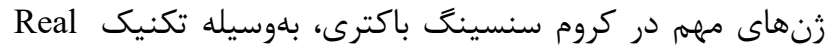

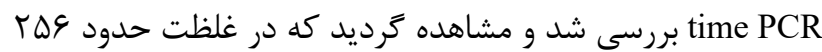
ميكروگرم در ميلىليتر عصارٔ سير يعنى غلظت بايين MIC اثر

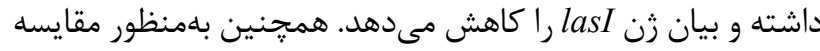
اثر كاهشى عصارٔ سير بر بيان اين زنها و اثر آنتىبيوتيك

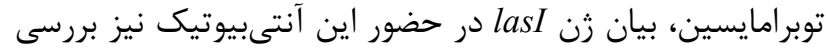

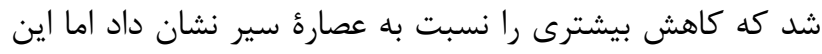

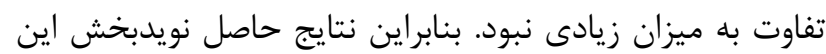

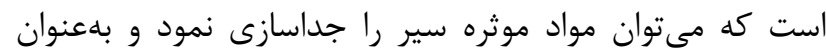

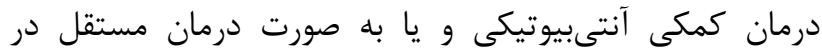
عفونتها مورد مصرف قرار داد. اين ماده موثره در تحقيق حاضر

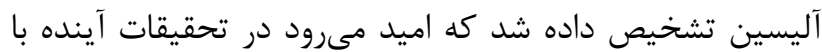
استخراج و خالصسازى آن و با انجام تحقيقات بيشتر، از آليسين

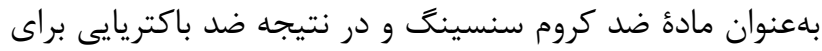
درمان عفونتهاى سودوموناس آئروزينوزا استفاده كردد. تعارض در منافع

ميان نويسند

\section{Referance}

1. Waters CM, Bassler BL. Quorum sensing: cell-to-cell communication in bacteria. Annu Rev Cell Dev Biol. 2005;21:319-46.

[DOI:10.1146/annurev.cellbio.21.012704.131001] [PMID]

2. Papenfort K, Bassler BL. Quorum sensing signalresponse systems in Gram-negative bacteria. Nature Reviews Microbiology. 2016;14(9):576. [DOI:10.1038/nrmicro.2016.89] [PMID] [PMCID]

3. Solano C, Echeverz M, Lasa I. Biofilm dispersion and quorum sensing. Current opinion in microbiology. 2014;18:96-104. [DOI:10.1016/j.mib.2014.02.008] [PMID]

4. Trappetti C, Oggioni MR. Biofilm Formation Under In Vitro Conditions. Streptococcus Pneumoniae: Elsevier; 2015. p. 245-55. [DOI:10.1016/B978-0-12410530-0.00013-2]

5. Oliver A, Mulet X, López-Causapé C, Juan C. The increasing threat of Pseudomonas aeruginosa high-
الاستاز و هموليزين نشان دادند. علاوه بر اين، تمام ينج تركيب بلهور

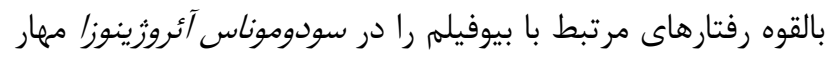

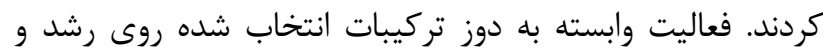
فعاليت ضد كروم سنسينگ در غلظتهاى مختلف مشاهده شد. در بررسى ميزان الاستاز LasB، به جز mangiferin، بقيه تركيبات

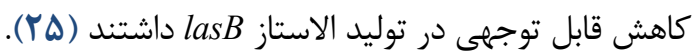
O'Loughlin و همكاران در سال rا.•r، طى مطالعه مهاركنندگى كروم سنسينگ و تشكيل بيوفيلم سودوموناس

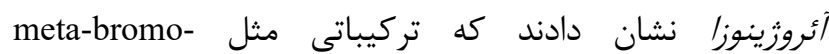

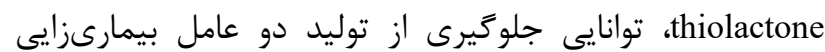

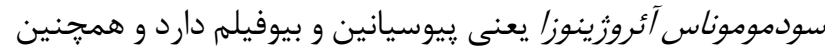

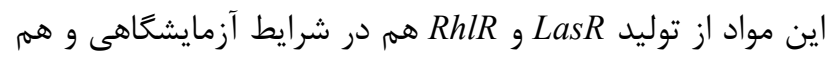

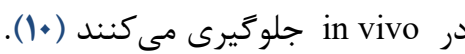

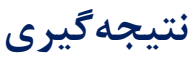

با توجه به آنجه كه بيان شد، اثر عصاره سير بر كروم

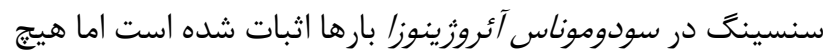
يك از تحقيقاتى كه به آنها اشاره شد، مكانيسه اين اثر را بيان نكرده و بيان زنهاى كروم سنسينگ را مورد بررسى قرار ندادهاند.

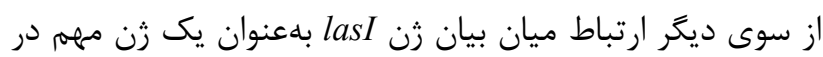
بديدة كروم سنسينگ، در تشكيل بيوفيلم نيز به خوبى بررسى إنى شده است اما اثر عصارٔ سير بر بيان اين زن مورد مطالعه قرار

risk clones. Drug Resistance Updates. 2015;21:4159. [DOI:10.1016/j.drup.2015.08.002] [PMID]

6. Brackman G, Coenye T. Quorum sensing inhibitors as anti-biofilm agents. Current pharmaceutical design. 2015;21(1):5-11. [DOI:10.2174/1381612820666140905114627] [PMID]

7. Truchado P, Larrosa M, Castro-Ibáñez I, Allende A. Plant food extracts and phytochemicals: their role as quorum sensing inhibitors. Trends in Food Science \& Technology. 2015;43(2):189-204. [DOI:10.1016/j.tifs.2015.02.009]

8. Bergey DH, Hendricks D, Holt JG, Sneath PH. Bergey's Manual of systematic bacteriology. Vol. 2: Williams \& Wilkins; 1984.

9. Bratu S, Gupta J, Quale J. Expression of the las and rhl quorum-sensing systems in clinical isolates of Pseudomonas aeruginosa does not correlate with efflux pump expression or antimicrobial resistance. Journal of Antimicrobial Chemotherapy. 
2006;58(6):1250-3.

[DOI:10.1093/jac/dk1407] [PMID]

10. O'Loughlin CT, Miller LC, Siryaporn A, Drescher K, Semmelhack MF, Bassler BL. A quorum-sensing inhibitor blocks Pseudomonas aeruginosa virulence and biofilm formation. Proceedings of the National Academy of Sciences. 2013;110(44):17981-6. [DOI:10.1073/pnas.1316981110] [PMID] [PMCID]

11. Zhou Y, Kong Y, Kundu S, Cirillo JD, Liang H. Antibacterial activities of gold and silver nanoparticles against Escherichia coli and bacillus Calmette-Guérin. Journal of nanobiotechnology. 2012;10(1):19. [DOI:10.1186/1477-3155-10-19]

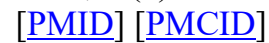

12. Narusaka M, Shiraishi T, Iwabuchi M, Narusaka Y. rpoD gene expression as an indicator of bacterial pathogens in host plants. Journal of General Plant Pathology. 2011;77(2):75-80. [DOI:10.1007/s10327011-0298-X]

13. Lewis K. Platforms for antibiotic discovery. Nature reviews Drug discovery. 2013;12(5):371-87. [DOI:10.1038/nrd3975] [PMID]

14. Reiter J, Hübbers AM, Albrecht F, Leichert LIO, Slusarenko AJ. Allicin, a natural antimicrobial defence substance from garlic, inhibits DNA gyrase activity in bacteria. International Journal of Medical Microbiology. 2020;310(1):151359. [DOI:10.1016/j.ijmm.2019.151359] [PMID]

15. Dwivedi VP, Bhattacharya D, Singh M, Bhaskar A, Kumar S, Fatima S, et al. Allicin enhances antimicrobial activity of macrophages during Mycobacterium tuberculosis infection. Journal of ethnopharmacology. 2019;243:111634. [DOI:10.1016/j.jep.2018.12.008] [PMID]

16. Choo S, Chin VK, Wong EH, Madhavan P, Tay ST, Yong PVC, et al. antimicrobial properties of allicin used alone or in combination with other medications. Folia Microbiologica. 2020:1-15. [DOI:10.1007/s12223-020-00786-5] [PMID]

17. Schuster M, Lostroh CP, Ogi T, Greenberg EP. Identification, timing, and signal specificity of Pseudomonas aeruginosa quorum-controlled genes: a transcriptome analysis. Journal of bacteriology. 2003;185(7):2066-79. [DOI:10.1128/JB.185.7.2066-

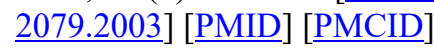

18. Smith RS, Harris SG, Phipps R, Iglewski B. The Pseudomonas aeruginosa quorum-sensing molecule $\mathrm{N}$-(3-oxododecanoyl) homoserine lactone contributes to virulence and induces inflammation in vivo. Journal of bacteriology. 2002;184(4):1132-9. [DOI:10.1128/jb.184.4.1132-1139.2002] [PMID] [PMCID]
19. Bazargani MM, Rohloff J. Antibiofilm activity of essential oils and plant extracts against Staphylococcus aureus and Escherichia coli biofilms. Food control. 2016;61:156-64. [DOI:10.1016/i.foodcont.2015.09.036]

20. Bjarnsholt $T$, Jensen $P Ø$, Rasmussen $T B$, Christophersen L, Calum H, Hentzer M, et al. Garlic blocks quorum sensing and promotes rapid clearing of pulmonary Pseudomonas aeruginosa infections. Microbiology. 2005;151(12):3873-80. [DOI:10.1099/mic.0.27955-0] [PMID]

21. Fulghesu L, Giallorenzo C, Savoia D. Evaluation of different compounds as quorum sensing inhibitors in Pseudomonas aeruginosa. Journal of chemotherapy. 2007;19(4):388-90.

[DOI:10.1179/joc.2007.19.4.388] [PMID]

22. Rasmussen TB, Bjarnsholt $\mathrm{T}$, Skindersoe ME, Hentzer M, Kristoffersen P, Köte M, et al. Screening for quorum-sensing inhibitors (QSI) by use of a novel genetic system, the QSI selector. Journal of bacteriology. 2005;187(5):1799-814. [DOI:10.1128/JB.187.5.1799-1814.2005] [PMID] [PMCID]

23. Bodini S, Manfredini S, Epp M, Valentini S, Santori F. Quorum sensing inhibition activity of garlic extract and p-coumaric acid. Letters in applied microbiology. 2009;49(5):551-5. 765X.2009.02704.X] [PMID]

24. Harjai K, Kumar R, Singh S. Garlic blocks quorum sensing and attenuates the virulence of Pseudomonas aeruginosa. FEMS Immunology \& Medical Microbiology. 2010;58(2):161-8. [DOI:10.1111/j.1574-695X.2009.00614.X] [PMID]

25. Annapoorani A, Umamageswaran V, Parameswari R, Pandian SK, Ravi AV. Computational discovery of putative quorum sensing inhibitors against LasR and RhlR receptor proteins of Pseudomonas aeruginosa. Journal of computer-aided molecular design. 2012;26(9):1067-77. [DOI:10.1007/s10822-0129599-1] [PMID] 